\title{
Productive variability, border use and plot size in trials with cherry tomato
}

\author{
Daniel Santos ${ }^{1}$ Alessandro Dal'Col Lúcio ${ }^{2 *}$ Sidinei José Lopes ${ }^{2}$ \\ Alberto Cargnelutti Filho $^{2}$ Tiago Olivoto ${ }^{2}$ \\ ${ }^{1}$ Instituto Federal de Santa Catarina (IFSC), São Carlos, SC, Brasil. \\ ${ }^{2}$ Departamento de Fitotecnia, Centro de Ciências Rurais (CCR), Universidade Federal de Santa Maria (UFSM), 97105-900, Santa Maria, RS, \\ Brasil. E-mail: adlucio@ufsm.br. "Corresponding author.
}

\begin{abstract}
Knowing the productive variability within protected environments is crucial for choosing the experimental design to be used in that conditions. Thus, the aim of the present study was to assess the variability of fruit production in protected environment cultivated with cherry tomatoes and to verify the border effect and plot size in reducing this variability. To this, data from an uniformity test carried out in a greenhouse with cherry tomato $\mathrm{cv}$. 'Lili'were used. Total fresh mass of fruits per plant was considered being these plants arranged in cropping rows parallel to the lateral openings of the greenhouse and also the same plants arranged in columns perpendicular to these openings. To generate the borders, different scenarios were designed by excluding rows and columns and using different plot sizes. In each scenario, homogeneity of variances among the remaining rows and columns was tested. There is no variability of fruit production among rows or columns in trials with cherry tomatoes carried out in greenhouses and the use of border does not bring benefits in terms of reduction of coefficient of variation or reduction of cases of variance heterogeneity among rows or columns. Plots with a size equal to or greater than two plants make possible to use the completely randomized design in the cherry tomato trials in greenhouses.
\end{abstract}

Key words: Lycopersicon esculentum var. cerasiforme, experimental design, experimental precision, olericulture, protected environment.

Variabilidade produtiva, uso de bordadura e tamanho de parcela em ensaios com tomate cereja

RESUMO: Conhecer a variabilidade dentro de ambientes protegidos é crucial para a escolha do delineamento experimental a ser utilizado nestas condições. O objetivo do estudo foi avaliar a variabilidade de produção de frutos em ambiente protegido cultivado com tomate cereja e, verificar o efeito do uso de bordaduras e tamanho de parcela na redução dessa variabilidade. Para isso, dados de um teste de uniformidade realizado em estufa com tomate cereja cv. 'Lili' foram utilizados. A massa fresca total de frutos por planta foi considerada, sendo estas plantas dispostas em fileiras de cultivo paralelas às aberturas laterais da estufa e, também, foram dispostas em colunas perpendiculares a estas aberturas. Para gerar as bordaduras, diferentes cenários foram projetados excluindo linhas e colunas, usando diferentes tamanhos de parcela. Em cada cenário, a homogeneidade das variâncias entre as fileiras e colunas restantes foi testada. Não há variabilidade na produção de frutos entre fileiras ou colunas em ensaios com tomate cereja, realizado em estufas, sendo que o uso de bordaduras não traz beneficios em termos de redução do coeficiente de variação ou dos casos de heterogeneidade de variância entre fileiras ou colunas. As parcelas com um tamanho igual ou superior a duas plantas tornam possível utilizar o delineamento inteiramente casualizado nos ensaios com tomate cereja em estufas.

Palavras-chave: Lycopersicon esculentum var. cerasiforme, ambiente protegido, delineamento experimental, olericultura, precisão experimental.

The heterogeneity in a trial inflates the estimate of experimental error directly interfering in the results of analyses and recommendations. The higher the experimental error, the greater the chances of the treatments under study be improperly discriminated, increasing the probability of occurrence of the type II error (STEEL et al., 1997). According to STEEL et al.
(1997), the experimental error can be minimized with the use of concomitant observations, adequate experimental design, and selection of appropriate experimental unit size and shape. Moreover, the determination of number of replicates and the sample size are also strategies to reduce the experimental error, might being adopted still at the experimental planning (STORCK et al., 2016). 
Trials with vegetable crops in protected environments might be as, or even more heterogeneous as those conducted in the field (LOPES et al., 1998; LÚCIO et al., 2008; SANTOS et al., 2012). In addition to soil heterogeneity, some particularities such as the presence or absence of fruits suitable to be harvested in a given crop, the multiple harvests that are made in some crops, and the more intensive cultural management in relation to other crops, also become sources of productive variability in trials carried out in these conditions (LÚCIO et al., 2008).

The existence of productive variability among cropping rows has justified the use of the randomized block design in protected environment trials, using those rows as a block (LÚCIO et al., 2006; LÚCIO et al., 2008; SANTOS et al., 2012). It is expected that this experimental design minimizes the effect of row productive variability on residual variance; however, if there is variability among columns arranged in the perpendicular direction of the rows, there may be variability within the block. This is worrying since the productive variability within the blocks increases the residual variance. In this context, the use of borders could also be an alternative to minimize the interaction of the rows or side columns of the greenhouse with the external environment, thus reducing variability in the trials.

Use of borders in the experimental plots is widely used in field experiments, aiming to reduce interplot competition (COCHRAN \& COX, 1986; STEEL et al., 1997, STORCK et al., 2016). For vegetable crops, no studies were carried out verifying if the use of borders could minimize interaction of lateral rows or columns of the greenhouse with the external environment. Thus, a more detailed study on this subject is needed in order to allow a greater experimental precision of future studies. Therefore, the aim of the present study was to assess the variability of fruit production in protected environments cultivated with cherry tomatoes and to verify the border effect and plot size in minimizing this variability.

The study was carried out with data from an uniformity trial with cherry tomato cv. 'Lili', conducted in the autumn season in the experimental area of the Department of Plant Science of the Universidade Federal de Santa Maria. The greenhouse used was a Pampean arch with the following dimensions: 2.0-m-height lateral post, $3.5-\mathrm{m}$-height central post, $20-\mathrm{m}$ long and 10-m wide, oriented in a north-south direction. The greenhouse cover was made with low-density polyethylene (LDPE) film, with a thickness of 150 microns and anti-UV additive.

The cropping rows were parallelly arranged to the greenhouse's openings, spaced at $0.8 \mathrm{~m}$ and covered with a black low-density polyethylene film (mulching). Each cropping row was composed of 30 plants spaced at $0.6 \mathrm{~m}$. Three harvests were carried out being the analyzed variable the total fresh mass of fruits (in $g$ per plant).

In order to carry out statistical analysis, it was considered the total fresh mass per plant, being those arranged in k-cropping rows (eight) parallel to the lateral opening of the greenhouse and also these same plants arranged in $\mathrm{j}$-columns (thirty) perpendicularly disposed to the lateral opening of the greenhouse. For each row and column, it was calculated the mean, variance and coefficient of variation by simulating different plot size, multiple of the number of plant per row, ranging from one to ten plants per plot. In each scenario, the adherence of data to normal distribution was tested by Lilliefors test and variance homogeneity among rows and columns by the Bartlett test.

In order to assess the border effect on the variability of fruit production, it was started from original scenario (JOK0) and new scenarios were designed by the exclusion of rows and columns in order to simulate the borders (Figure 1). For this, at each end of the lateral opening one row was excluded, simultaneously. The columns, conversely, were excluded one-by-one, simultaneously, at each end of the greenhouse up to $50 \%$ of columns remained. This procedure was carried out in different plot size, ranging from one to ten plants within cropping row.

In each plot size of each scenario of row exclusion, column exclusion or combination of row and column exclusion, a new variance, and coefficient of variation for the rows and columns remaining were calculated. A new Bartlett test was performed. Statistical analyses were performed with SAEG 9.1 and Excel software, at $5 \%$ error probability.

The data have adhered to the normal distribution and there were no cases of variances heterogeneity among rows or columns independently of the use or not of borders, in neither of the scenarios or plot sizes tested. This result agrees with LÚCIO et al. (2016) for the cherry tomato; however, it disagrees with those observed by LÚCIO et al. (2010) for salad tomato. 


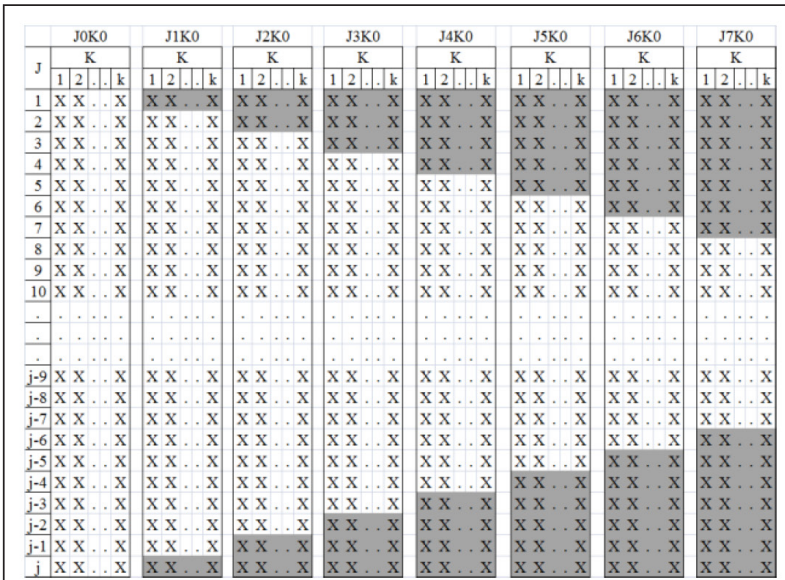

(A)
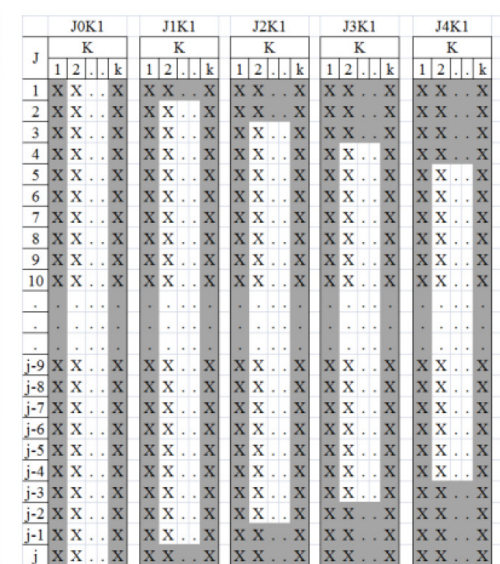

(B)

Figure 1 - Schematic representation of plants $(X)$ arranged in rows $(K=8)$ and columns $(\mathrm{J}=30)$, with the scenarios designed by the exclusion of columns (A) and rows and columns (B). The exclusions are highlighted in gray.

The lower productive variability among rows for cherry tomato was due the number of harvests performed. Whereas in this study were carried out only three harvests, for salad tomato, 12 harvests were performed (LÚCIO et al., 2010).

The use of borders consisting of rows and/or columns did not influence the result of the homogeneity test of variances among rows. Therefore, this technique is not recommended in trials with cherry tomatoes in greenhouses, since in addition to not reducing the variability, the useful area of trials would be decreased.

As there were no cases of variances heterogeneity among rows or columns, it is possible to use the completely randomized design in the trials with this crop. LOPES et al. (1998) studying experimental techniques for salad tomato, also suggested the possibility of using the completely randomized design. The same authors also proved that the use of plots with a size smaller than 18 plants and completely randomized design are sufficient to detect differences superior to $7 \%$ of the mean among treatments. According to STORCK et al. (2016), whenever a homogeneous experimental unit is available, the completely randomized design should be preferred, since it is more flexible in relation to the number of repetitions and treatments, besides allowing the greatest number of possible degrees of freedom for the experimental error, resulting in a greater accuracy.
Our results suggested that the completely randomized design could be fully used in cherry tomato trials in greenhouse independently of the plot size. However, there is an increase in the risk of plots constituted of only one plant be lost. Thus, the most coherent approach is to use the completely randomized design with a plot size greater than or equal to two plants. This situation was also reported by LÚCIO et al. (2016) who verified that the minimal plot size for cherry tomatoes was three and seven plants each cropping row for growth and productive characteristics, respectively.

With the increase in plot size there was a decrease in the productive variability among the plots and a reduction in the coefficient of variation, independently of designed scenarios (Table 1). This behavior was also reported by LÚCIO et al. (2010) who reported that there are increases in the variance estimates of the fresh fruit mass with the increase of the plot size and/or the number of grouped. The same authors also reported that plots composed of four plants in the cropping row combined with a grouping of six in six Harvests reduce variability.

There is no variability of fruit production among rows or columns in cherry tomato trials carried out in greenhouses. The use of borders consisting of lateral rows or columns perpendicular to the sides of the greenhouse does not bring benefits in terms of reduction of coefficient of variation or variability of fruit production among rows or columns. Thus, the 
Table 1 - Variance $\left(\mathrm{s}^{2}\right.$ in $\left.\mathrm{g}^{2} .10^{5}\right)$ and coefficient of variation (CV in percentage) for the fresh mass of fruits of cherry tomato in the different scenarios designed by the exclusion of rows $(K=8)$ and columns $(\mathrm{J}=30)$ in different plot size.

\begin{tabular}{|c|c|c|c|c|c|c|c|c|c|c|}
\hline \multirow[b]{2}{*}{ Scenario } & & \multicolumn{9}{|c|}{ 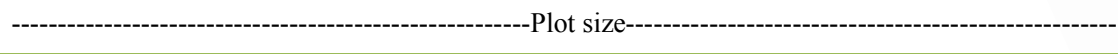 } \\
\hline & & 1 & 2 & 3 & 4 & 5 & 6 & 7 & 8 & 10 \\
\hline \multirow[t]{2}{*}{ J0K0 } & $\mathrm{s}^{2}$ & 2.78 & 6.87 & 10.98 & - & 23.70 & - & - & - & 72.14 \\
\hline & $\mathrm{CV}$ & 33.06 & 25.70 & 21.85 & - & 19.31 & - & - & - & 16.70 \\
\hline \multirow[t]{2}{*}{$\mathrm{J} 1 \mathrm{~K} 0$} & $\mathrm{~s}^{2}$ & 2.68 & 5.68 & - & 18.11 & - & - & 36.20 & - & - \\
\hline & $\mathrm{CV}$ & 33.06 & 23.85 & - & 21.56 & - & - & 17.05 & - & - \\
\hline \multirow[t]{2}{*}{$\mathrm{J} 2 \mathrm{~K} 0$} & $\mathrm{~s}^{2}$ & 2.64 & 6.55 & - & - & - & - & - & - & - \\
\hline & $\mathrm{CV}$ & 33.35 & 25.85 & - & - & - & - & - & - & - \\
\hline \multirow[t]{2}{*}{$\mathrm{J} 3 \mathrm{~K} 0$} & $\mathrm{~s}^{2}$ & 2.70 & 5.75 & 10.98 & 15.34 & - & 31.25 & - & 52.32 & - \\
\hline & $\mathrm{CV}$ & 34.41 & 24.77 & 22.88 & 20.41 & - & 19.42 & - & 18.84 & - \\
\hline \multirow[t]{2}{*}{$\mathrm{J} 4 \mathrm{~K} 0$} & $\mathrm{~s}^{2}$ & 2.73 & 6.56 & - & - & - & - & - & - & - \\
\hline & $\mathrm{CV}$ & 35.10 & 26.71 & - & - & - & - & - & - & - \\
\hline \multirow[t]{2}{*}{$\mathrm{J} 5 \mathrm{~K} 0$} & $\mathrm{~s}^{2}$ & 2.64 & 5.84 & - & 18.62 & 23.09 & - & - & - & - \\
\hline & $\mathrm{CV}$ & 34.67 & 25.33 & - & 23.07 & 20.41 & - & - & - & - \\
\hline \multirow[t]{2}{*}{ J6K0 } & $\mathrm{s}^{2}$ & 2.53 & 5.96 & 10.06 & - & - & 29.90 & - & - & - \\
\hline & $\mathrm{CV}$ & 33.53 & 25.15 & 22.18 & - & - & 18.95 & - & - & - \\
\hline \multirow[t]{2}{*}{$\mathrm{J} 7 \mathrm{~K} 0$} & $\mathrm{~s}^{2}$ & 2.41 & 5.31 & - & 13.37 & - & - & - & - & - \\
\hline & $\mathrm{CV}$ & 32.41 & 23.48 & - & 19.06 & - & - & - & - & - \\
\hline \multirow[t]{2}{*}{$\mathrm{J} 0 \mathrm{~K} 1$} & $\mathrm{~s}^{2}$ & 2.49 & 6.24 & 9.58 & - & 20.01 & - & - & - & 55.66 \\
\hline & $\mathrm{CV}$ & 30.58 & 24.14 & 20.00 & - & 17.51 & - & - & - & 14.48 \\
\hline \multirow[t]{2}{*}{$\mathrm{J} 1 \mathrm{~K} 1$} & $\mathrm{~s}^{2}$ & 2.50 & 5.30 & - & 17.15 & - & - & 31.58 & - & - \\
\hline & $\mathrm{CV}$ & 30.97 & 22.43 & - & 20.40 & - & - & 15.75 & - & - \\
\hline \multirow[t]{2}{*}{$\mathrm{J} 2 \mathrm{~K} 1$} & $\mathrm{~s}^{2}$ & 2.48 & 6.60 & - & - & - & - & - & - & - \\
\hline & $\mathrm{CV}$ & 31.19 & 25.36 & - & - & - & - & - & - & - \\
\hline \multirow[t]{2}{*}{$\mathrm{J} 3 \mathrm{~K} 1$} & $\mathrm{~s}^{2}$ & 2.57 & 5.53 & 11.15 & 14.98 & - & 32.36 & - & 50.44 & - \\
\hline & $\mathrm{CV}$ & 32.41 & 23.60 & 22.63 & 19.69 & - & 19.29 & - & 18.10 & - \\
\hline \multirow[t]{2}{*}{$\mathrm{J} 4 \mathrm{~K} 1$} & $\mathrm{~s}^{2}$ & 2.67 & 7.10 & - & - & - & - & - & - & - \\
\hline & $\mathrm{CV}$ & 33.63 & 27.23 & - & - & - & - & - & - & - \\
\hline \multirow[t]{2}{*}{ J5K1 } & $\mathrm{s}^{2}$ & 2.53 & 5.49 & - & 18.25 & 23.66 & - & - & - & - \\
\hline & $\mathrm{CV}$ & 32.58 & 23.84 & - & 22.11 & 20.20 & - & - & - & - \\
\hline \multirow[t]{2}{*}{ J6K1 } & $\mathrm{s}^{2}$ & 2.62 & 6.85 & 11.42 & - & - & 34.27 & - & - & - \\
\hline & $\mathrm{CV}$ & 33.22 & 26.49 & 23.31 & - & - & 20.14 & - & - & - \\
\hline \multirow[t]{2}{*}{$\mathrm{J} 7 \mathrm{~K} 1$} & $\mathrm{~s}^{2}$ & 2.36 & 4.98 & - & 13.85 & - & - & - & - & - \\
\hline & $\mathrm{CV}$ & 31.25 & 22.35 & - & 19.08 & - & - & - & - & - \\
\hline
\end{tabular}

use of plots with a size greater than or equal two plants make it possible using a completely randomized design in trials with cherry tomatoes in greenhouses.

\section{ACKNOWLEDGEMENTS}

We would like to thank the Conselho Nacional de Desenvolvimento Científico e Tecnológico (CNPq) for their financial support and the grant of scholarships for productivity in research

\section{REFERENCES}

COCHRAN, W.;COX, G. Experimental design. 2ed. New York: John Wiley \& Sons, 1986.459pp.

LOPES, S.J. et al. Salad tomato experimental techniques in plastic greenhouse. Ciência Rural, v. 28, n. 2, p. 193-197, 1998. Available from: <http://www.scielo.br/scielo.php?script=sci ar ttext\&pid=S0103-84781998000200002>. Accessed: May 10, 2017. doi: 10.1590/S0103-84781998000200002. 
LÚCIO, A.D. et al. Variance and means of zucchini fruit mass in multiple harvests. Horticultura Brasileira, v. 26, n. 3, p. 335-341, 2008. Available from: <http://www.scielo.br/pdf/hb/v26n3/09.pdf $>$. Accessed: May, 10, 2017. doi: 10.1590/S0102-05362008000300009.

LÚCIO, A.D. et al. Grouping in tomato harvests and estimates of the plot size in protected environment. Horticultura Brasileira, v. 28, n. 2, 2010. Available from: <http://www.scielo.br/scielo. php?script=sci_arttext\&pid=S0102-05362010000200009> Accessed: May 10,2017.doi: 10.1590/S0102-05362010000200009.

LÚCIO, A.D. et al. Heteroscedasticity between rows and harvests of cherry tomato yield characters and estimate of the plot size. Horticultura Brasileira, v. 34,n. 2, 2016. Available from: $<$ http://www. scielo.br/scielo.php?pid=S0102-05362016000200223\&script $=$ sci abstract\&tlng=pt $>$. Accessed: May 10, 2017. doi: 10.1590/S0102053620160000200012 .
LÚCIO, A.D. et al. Temporal variation of the production of peppers affected by plants position and morphologic characteristics of protected crop. Horticultura Brasileira, v. 24, n. 1, p. 3135, 2006. Available from: <http://www.scielo.br/pdf/hb/v24n1/ a07v24n1.pdf $>$. Accessed: May 10, 2017. doi: 10.1590/S010205362006000100007.

SANTOS, D. et al. Randomness and variability productive of bean pod. Ciência Rural, Santa Maria, v. 42, n. 7, p. 1147-1154, 2012. Available from: <http://revistas.bvs-vet.org.br/crural/article/ view/21439/22262>. Accessed: May 10, 2017.

STEEL R.G.D et al. Principles and procedures of statistics: a biometrical approach. 3ed. New York: McGraw-Hill,1997. 666p.

STORCK L. et al. Experimentação Vegetal. 3ed. Santa Maria: Editora UFSM, 2016. 198p. 